\title{
Migrant Common Eider, Somateria mollissima, Collisions with Power Transmission Lines and Shortwave Communication Towers on the Tantramar Marsh in Southeastern New Brunswick
}

\author{
Colin M. MACKInNON ${ }^{1}$ and ANDREW C. KENNEDY ${ }^{1}$ \\ ${ }^{1}$ Canadian Wildlife Service, Environment Canada, P. O. Box 6227, Sackville, New Brunswick E4L 1G6 Canada
}

MacKinnon, Colin M., and Andrew C. Kennedy. 2011. Migrant Common Eider, Somateria mollissima, collisions with power transmission lines and shortwave communication towers on the Tantramar Marsh in southeastern New Brunswick. Canadian Field-Naturalist 125(1): 41-46.

Between 1971 and 2009, 85 dead, injured, or grounded Common Eiders, Somateria mollissima, were recorded on the Tantramar Marsh in southeastern New Brunswick, apparently the result of collisions with power transmission lines and shortwave communication towers. Of 82 location observations, $53(65 \%)$ were near a series of power transmission lines and $21(26 \%)$ were in the vicinity of shortwave communication towers. Of the 85 birds observed, $43(51 \%)$ were found dead, $18(21 \%)$ were found alive on the ground with undetermined injuries, $5(6 \%)$ were found alive with broken wings, and 9 birds $(11 \%)$ were found alive with no obvious external injuries and were released in water. A further 10 live birds (12\%) were observed on small bodies of water and appeared unable to fly. Occurrences appear to be predominantly during fall migration, with most sightings recorded between 9 October and 21 December $(99 \%, n=73)$. The effects of cumulative mortality on Common Eiders should be considered if further infrastructure within the Tantramar Marsh or infrastructure involving other known overland routes used by Common Eiders during migration is proposed.

Key Words: Common Eider, Somateria mollissima, Tantramar Marsh, Chignecto Isthmus, New Brunswick, power transmission lines, shortwave towers, communication towers, fall migration, bird strikes.

\section{Introduction}

Along the East Coast of North America, Common Eiders are legally harvested as well as being the most abundant species of seaduck. Breeding populations have been recently estimated to be 18000 pair in Labrador, 3000 in Newfoundland and $18000-22000$ in New Brunswick and Nova Scotia (Canadian Wildlife Service Waterfowl Committee 2010). During fall migration, the Somateria mollissima dresseri subspecies is known to cross the narrow isthmus, including the Tantramar Marsh, between New Brunswick and Nova Scotia for wintering areas to the south (Goudie et al. 2000) (Figure 1).

The Tantramar Marsh $\left(67 \mathrm{~km}^{2}\right)$, including the Tantramar River and Aulac River drainages, is situated in south-eastern New Brunswick, near the town of Sackville, and immediately west-northwest of the Missaguash Marsh which separates New Brunswick from Nova Scotia $\left(45^{\prime} 55^{\circ} \mathrm{N}, 64^{\prime} 18^{\circ} \mathrm{W}\right)$. Located at the head of Cumberland Basin, which is at the northeastern extremity of the Bay of Fundy, the Tantramar Marsh consist predominantly of agricultural lands that have been reclaimed from the sea by a series of dykes, a tide control gate, and an aboiteau (a wooden sluice underneath a dyke used to maintain drainage) (Figure 2).

These tidal barriers protect not only agricultural land but also important transportation and communication infrastructure (the Trans-Canada Highway, a Canadian National Railway line, Radio Canada International

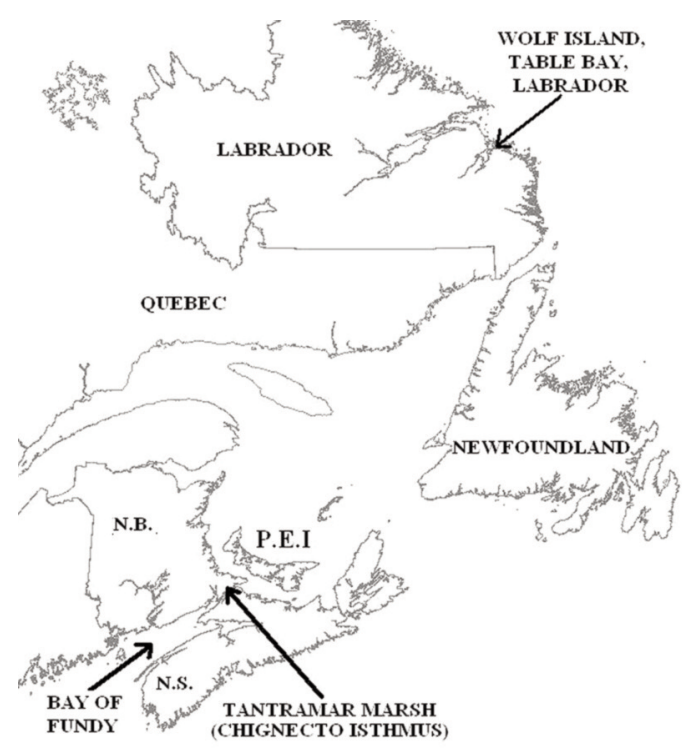

FiguRE 1. Location of the Tantramar Marsh (Chignecto Isthmus) situated on the border between New Brunswick and Nova Scotia; Baie Verte (Northumberland Strait) to the northeast and Cumberland Basin (Bay of Fundy) to the southwest. Note the "Wolf Island", Labrador banding location for the Common Eider found on the Tantramar Marsh (see text for details). 
station, and three major power transmission lines). This area also constitutes part of the Chignecto Isthmus, where, at the narrowest point, the Northumberland Strait (Baie Verte) to the north and the Bay of Fundy (Cumberland Basin) to the south are separated by a land mass only $24 \mathrm{~km}$ wide (see MacKinnon and Kennedy 2009). The Tantramar Marsh, situated between these two larger bodies of tidal waters, is the site of overland migration by Common Eiders.

Observations of Common Eiders crossing over land at certain locations within the Maritimes (New Brunswick, Nova Scotia, and Prince Edward Island) are not new (Tufts 1961; Boyer 1966; MacKinnon et al. 1991*; Goudie et al. 2000; Bond et al. 2007; Nature New Brunswick 2008). More specifically, Erskine and Smith (1986) went into much greater detail in their review of the status and movements of Common Eider ducks within the Maritimes, with particular reference to the birds' northward movements from the Bay of Fundy to the Northumberland Strait. Gauthier et al. (1976) noted that this less common option of overland migration by Common Eiders likely represents an added risk compared to following the Nova Scotia coastline offshore.

This paper summarizes observations of downed, injured, or dead Common Eiders on the Tantramar Marsh. We have assembled records from a number of observers and compared the locations in those records, along with our own detailed observations, with the location of anthropogenic structures within the boundaries of the study area. Although it is known that dead Common Eiders are frequently encountered on the isthmus, we seek to determine when this is most likely to occur and what is causing the mortality.

\section{Study Area}

The Tantramar Marsh consist of a wide-open expanse of un-forested, flat grasslands (agricultural hay and pasture lands) bordered by gently rising uplands to the west (town of Sackville, New Brunswick) and a narrow finger of land known locally as the Aulac Ridge to the east. In the late 19 th and early 20 th centuries, this farmland was dotted with hundreds of "marsh barns," reflective of a highly valuable hay crop; few of these structures survive today (MacKinnon 2000). The northern extremity of the marsh is bordered by a matrix of spruce (Picea)-fringed sphagnum bogs, lakes, and wooded swamps with gently rising ground farther inland. The southern flank bounds the curving north shore of Cumberland Basin (Figure 2). Across the southern edge of this area (from roughly east to west) lies the Trans-Canada Highway as well as the main Canadian National Railway line connecting Canada's eastern seaboard to destinations west. The High Marsh Road (Jolicure Road) runs parallel to, and $4.5 \mathrm{~km}$ north of, the Trans-Canada Highway. This secondary road connects Upper Sackville to the village of Jolicure and eventually merges with Route No. 16.

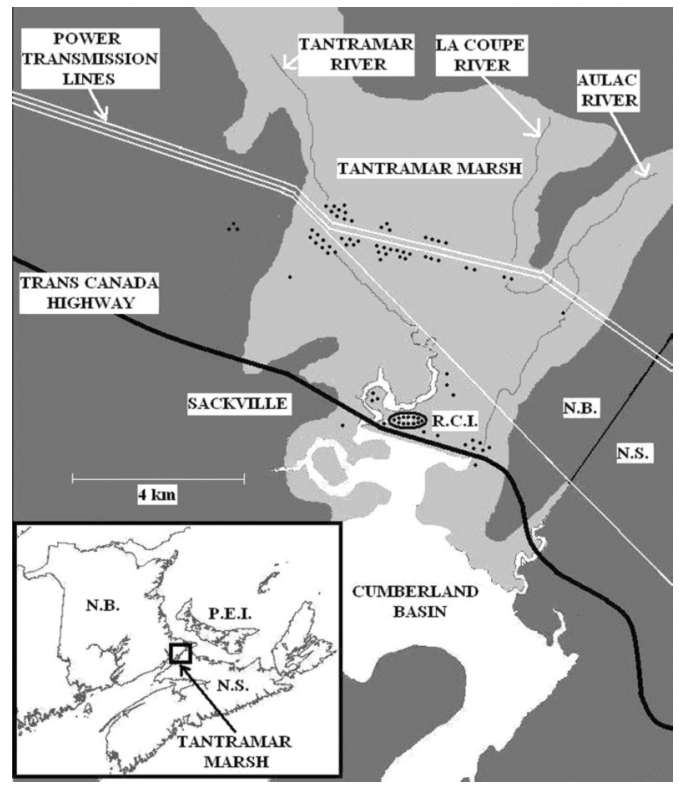

FIGURE 2. Locations of salient features of the Tantramar Marsh, New Brunswick. Note the locations of the power transmission lines as well as the Radio Canada International (RCI) facility immediately east of the Tantramar River. Baie Verte is situated $14 \mathrm{~km}$ to the northeast of the map. The "High Marsh Road" runs parallel and immediately south of the double row of power transmission lines. Approximate locations of downed Common Eiders are represented by black dots $(n=82)$.

Immediately north of the Trans-Canada Highway and centered within the Tantramar Marsh, is a small ( $~ 50$ ha) area of elevated land known as Coles Island, site of the Radio Canada International station. This communications facility began operation in 1943; shortwave service followed in 1945 (Figure 3). The Radio Canada International operation is predominantly a large "curtain array" consisting of numerous support cables with a grid of wires strung between 13 metal-framed towers. These towers are arranged in a semicircle extending horizontally for approximately $1200 \mathrm{~m}$. The tallest towers in the middle of the array reach a maximum height of $131 \mathrm{~m}$. With a broadcast power reaching 500000 watts, the Radio Canada International station can broadcast shortwave communications to all corners of the globe.

There is a series of three power transmission corridors that cross the Tantramar Marshes. Each corridor contains a series of parallel high-voltage transmission cables. These consist of a single $345 \mathrm{kV}$ line running from Memramcook, New Brunswick, to Onslow, Nova Scotia, and two additional lines (138 kV each) that connect Memramcook to Maccan and Springhill, Nova Scotia. These lines enter the marsh in close proximity to one another, along the western boundary of the 


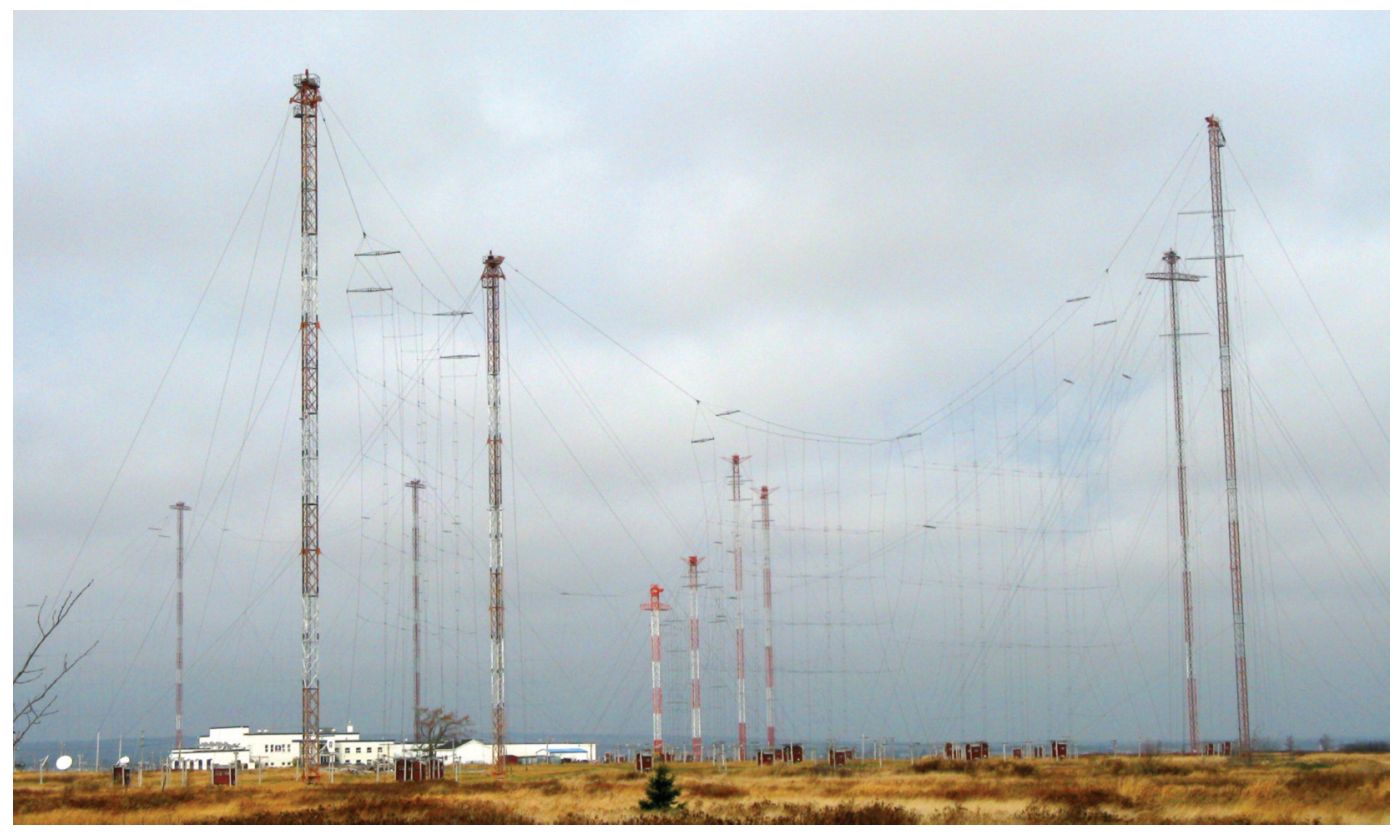

FiguRE 3. Radio Canada International station situated on Coles Island within the Tantramar Marsh near Sackville, New Brunswick. There is a complex matrix of wires/guy lines between the towers. The tallest feature is $131 \mathrm{~m}$. Photo: C. MacKinnon.

Tantramar, about $1 \mathrm{~km}$ northwest of the High Marsh Road. At a point $200 \mathrm{~m}$ north of the covered bridge that crosses the Tantramar River, these lines split (Figure 4). Two sets of parallel lines (one with metal lattice support towers and one with wooden poles) run across the marsh, west to east, just north of the High Marsh Road. The third set of lines, supported by both metal and wooden towers, runs diagonally across the marsh from the northwest to the southeast.

\section{Methods}

All Common Eiders recorded in this study were "downed" (found on the ground or water) within the Tantramar Marsh; the observer, date, and location were recorded when either a live duck or a carcass was found. Similar observations were collected by a number of volunteers. The authors kept more detailed records throughout all of 2008 and 2009. We attempted to record unit of effort, but the sporadic nature of the observations, as well as inaccessibility of portions of the study area, made direct comparisons difficult.

Locations of reported killed/injured/downed Common Eiders were recorded using the Universal Transverse Mercator (UTM) military grid reference on the National Topographic Map Series, Amherst 21H/16 (1:50 000 scale). The locations of these records were then compared to the locations of the three power transmission lines and the Radio Canada International tower array within the study area.

\section{Results and Discussion}

Common Eiders are reluctant to fly overland (Gauthier et al. 1976). However, the narrowness of the Chignecto Isthmus and resulting short flight distance $(\sim 24 \mathrm{~km})$ between the Bay of Fundy and the Northumberland Strait provides these birds with a much shorter alternative than the approximately $2200 \mathrm{~km}$ coastal route, including Cape Breton, around Nova Scotia (Erskine and Smith 1986; MacKinnon et al. 1991*; Bond et al. 2007). Such observations are not new: in 1973, W. B. Hughson reported seeing flocks ranging from 32 to 175 birds (at altitudes between 32 and 137 m) on 1, 2, 4, and 9 October 1973. These birds were flying in a southwesterly direction over the Tintamarre National Wildlife Area; located along the northern periphery of the Tantramar Marsh. On 4 October, Hughson estimated that over 1000 birds passed overhead between 16:15 and 19:35 (Hughson 1973*).

It has been suggested that overland migration by Common Eiders increases the risk that they will not complete the journey. Some of this risk may include losing direction while crossing overland and becoming exhausted due to inclement weather and unpredictable storms, as well as the chance of striking ground-based objects (Gauthier et al. 1976). Such accidents may be natural, such as an encounter with trees over a height of land, but accidents may also involve collisions with anthropogenic structures. Regardless of cause, it is generally assumed that once a Common Eider is on 


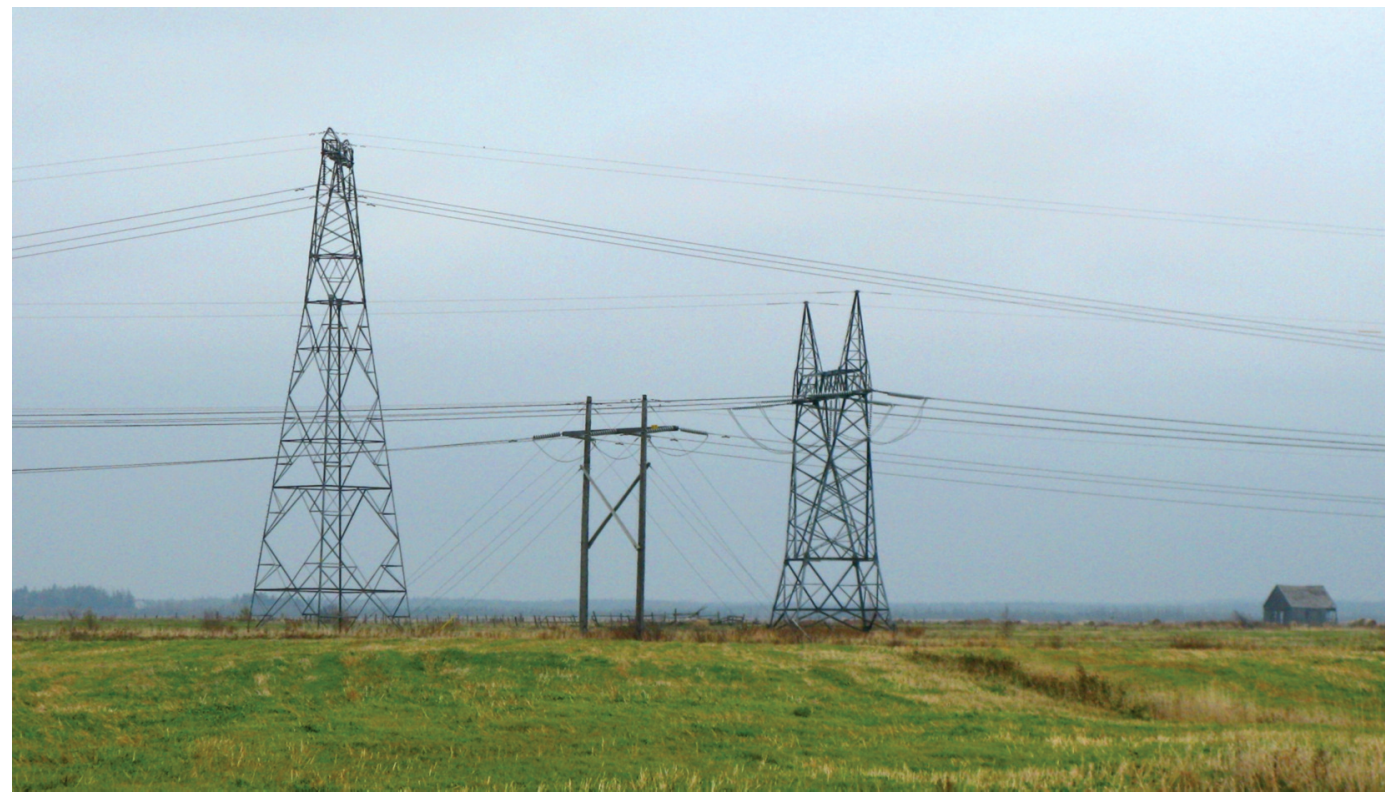

FIGURE 4. Intersection of three transmission lines north of the covered bridge on the High Marsh Road (Jolicure Road), Tantramar Marsh, New Brunswick, the site of numerous Common Eider collisions. Photo: A. Kennedy.

the ground away from open water, it may be difficult for it to regain flight. Furthermore, once grounded, these birds make easy prey for a variety of predators and often, based on the numbers of predated carcasses we observed, have little chance of survival.

We presumed that Common Eiders found on the ground within the treeless study area had flown into anthropogenic structures, such as nearby power transmission lines and communication towers. There are numerous records of such occurrences throughout the greater Chignecto Isthmus (see Nature New Brunswick 2008), although, in general, most observations are anecdotal and the details of the incidents are not always clear.

\section{Locations of Common Eiders recovered on the Tantra-} mar Marsh

Of the 82 detailed location records, 53 (65\%) Common Eiders were found along the 6.0-km-long section of road and adjacent power transmission corridor that cross the upper part of the Tantramar Marsh (generally from the covered bridge over the Tantramar River to the bridge over the La Coupe River). An additional 21 (26\%) were recovered under, or in close proximity to, the Radio Canada International towers at Coles Island, while the remaining $8(10 \%)$ were recovered from other locations within the study area (Figure 1).

\section{Timing of Common Eider collisions}

Of 74 observations of Common Eiders with known dates of occurrence, all but one (3 July 2007) occurred between 9 October and 21 December. There were more occurrences in October $(n=35,47 \%)$ than in November $(n=22,30 \%)$ or December $(n=16,22 \%)$. There have been a few reports of dead birds found in the April-May period, but these reports have been mostly wing remnants that, in all likelihood, were from incidents that had occurred late the previous fall, the carcasses being covered by snow and protected from scavengers over the winter months.

\section{Condition of recovered Common Eiders}

Of the 85 birds observed, $43(51 \%)$ were found dead, $18(21 \%)$ were alive but were found on the ground with undetermined injuries, $5(6 \%)$ were found alive with broken wings, and 9 birds (11\%) were found alive with no obvious external injuries and were released in water. A further 10 live birds (12\%) were observed on small bodies of water and appeared unable to fly.

\section{Incident observations and weather conditions}

C. M. M. and A. C. K. made detailed observations during 2008 and 2009. We recorded 17 and 25 observations of Common Eiders, respectively. In 2008, these observations were all single records, with the exception of 4 birds recorded on 25 October. These 4 birds likely collided with the Radio Canada International towers during the night or early morning hours of 24/25 October; weather conditions may have been a contributing factor. Throughout the evening of 24 October 2008, the temperature dropped from $7.8^{\circ} \mathrm{C}$ at $18: 00$ to $4.3^{\circ} \mathrm{C}$ at midnight. Wind speed throughout the evening was a 
relatively constant $7-9 \mathrm{~km} / \mathrm{h}$ from the south. The temperature had dropped to $-1.1^{\circ} \mathrm{C}$ by $03: 00$ and was still below freezing $\left(-0.8^{\circ} \mathrm{C}\right)$ at 07:00 on 25 October. Wind speed remained very light, still predominantly from the south, at $6-9 \mathrm{~km} / \mathrm{h}$ during this same period (Environment Canada* 2008).

It may be noteworthy that the night of 24/25 October had the heaviest frost of the fall up to that date. Relative humidity ranged from 94 to $97 \%$ in the early morning hours, vehicle windows were lightly covered with ice, and the ground was covered with a heavy frost. The moon was full on 14 October and a new moon followed on 28 October. This means there would have been relatively little if any natural light on the night of $24 / 25$ October. The Tantramar is known to have frequent and transient pockets of fog that would not be recorded by nearby weather stations. There could have been some ground fog on 24/25 October, but we have no record or indication that there was. It would appear that a combination of a dark, relatively still night, clear air, and possibly scant light reflecting on frozen ground culminated in more than one bird, likely from a larger flock, or flocks, hitting obstacles and being brought to ground at a variety of locations.

Of the 25 observations in 2009, three groups of birds (12 birds on 9 October, 5 birds on 12 November, and 4 birds on 19 December) were recorded, in addition to observations of individual birds. For the largest event, a number of people reported dead or injured/downed Common Eiders scattered in the study area on 9 October. The early morning hours were calm with light winds $(\sim 10 \mathrm{~km} / \mathrm{h})$ out of the north-northwest. Temperature was $\sim 7^{\circ} \mathrm{C}$ with $94 \%$ relative humidity. At sunrise, most of the Tantramar was blanketed with patches of low-lying fog. As the remains of dead Common Eiders were being quickly scavenged by Common Ravens (Corvus corax) and American Crows (Corvus brachyrhynchos), the Common Eiders must have collided with the transmission lines earlier that same day during foggy conditions. Of the 12 birds, 8 (66.6\%) were found near the power transmission lines, one $(8.3 \%)$ was found near the Radio Canada International towers, and $3(25 \%)$ were observed away from adjacent structures.

\section{Band recovery}

We do not have detailed information on where the Common Eiders that cross the isthmus originate. Of particular interest was a single banded bird recovered on 20 October 2009 by Chris Novak (Sackville, 392 Main Street, Sackville, New Brunswick E4L 3H6), who provided the following observations: "I found a banded eider in the ditch with a severely broken wing and emaciated. I assume it clipped the power lines along Folkins Drive (45 $\left.55^{\prime} 04^{\prime \prime} \mathrm{N}, 64^{\circ} 20^{\prime} 12^{\prime \prime} \mathrm{W}\right)$ as the broken wing is the only injury I can visually notice". That bird, number 1307-50171, was banded by Katherine Mehl on 18 August 2007 as an after hatch year male on Wolf Island, Table Bay, Newfoundland and Labrador, $76 \mathrm{~km}$ northeast of Cartwright, Labrador (Randy Hicks, Wildlife Technician, Canadian Wildlife Service, Environment Canada, Box 6227, 17 Waterfowl Lane, Sackville, New Brunswick E4L 1G6) (Figure 1).

\section{Conclusion}

The fall migration of Common Eiders across the Tantramar Marsh and the likelihood of the birds colliding with anthropogenic structures impose a flight risk to these birds. Most recoveries of downed, injured, or dead Common Eiders have been attributed to collisions either with power transmission lines or with the array of lines and towers associated with the Radio Canada International station at Coles Island. These accidents may be more frequent during times of bad weather and poor visibility. The total number of Common Eiders that cross the isthmus in the fall and the impact of these losses on subpopulations are lacking. Modification of the existing features to lessen the risk may not be possible; however, the effects of cumulative mortality on the Common Eider should be considered if further infrastructure within the Tantramar Marsh or infrastructure involving other known overland migratory routes of the Common Eider is proposed.

\section{Acknowledgements}

The authors would like to thank the many people who have taken time to record their observations. We would especially like to thank K. Popma and R. Miller, who have spent many hours surveying and recording wildlife observations on the Tantramar. Observations by A. Campbell, D. W. Colpitts, R. Daury, P. Hicklin, A. Hicks, R. Hicks, N. MacKinnon, K. McAloney, N. McLellan, C. Novak, J. Paquet, and J. Stewart have been most helpful. We also acknowledge the valuable records held by Nature New Brunswick (provided by their members) as a source of historical observations of mortalities of Common Eiders in southeastern New Brunswick. We would like to thank Paul Chamberland, Peter Hicklin, and Nancy MacKinnon for reviewing this paper. This paper greatly benefited from suggestions provided by A. J. Erskine as well as an anonymous reviewer.

Documents Cited (marked * in text)

Environment Canada. 2008. National Climate Data and Information Archive, Environment Canada, www.climate .weatheroffice.gc.ca

(accessed 5 November 2008).

Hughson, W. B. 1973. Common Eider observations over the Tintamarre National Wildlife Area. Memorandum dated 25 October 1973. Canadian Wildlife Service, Environment Canada, Sackville, N.B. 3 pages.

MacKinnon, C. M., R. W. Daury, and R. J. Hicks. 1991. Seabird and Seaduck Movement through the Northumberland Strait, 1990. Canadian Wildlife Service Technical Report Number 130. Canadian Wildlife Service - Atlantic Region, Environment Canada. 86 pages. 


\section{Literature Cited}

Bond, A. L., P. W. Hicklin, and M. Evans. 2007. Daytime spring migrations of scoters (Melanitta spp.) in the Bay of Fundy. Waterbirds 30: 566-572.

Boyer, G. F. 1966. Birds of the Nova Scotia-New Brunswick border region. Canadian Wildlife Service Occasional Paper Number 8. Second edition. Canadian Wildlife Service, Ottawa, Ontario. 52 pages.

Canadian Wildlife Service Waterfowl Committee. 2010. Population Status of Migratory Birds in Canada: November 2010. Canadian Wildlife Service Migratory irds Regulatory Report Number 31, 95 pages. http://www.ec.gc.ca/ Publications/default.asp?lang=En \&xml=0E5C278E-492F49A6-A8F9-CA3F7E45FEF7 (accessed 26 May 2011).

Erskine, A. J., and A. D. Smith. 1986. Status and movements of Common Eiders in the Maritime provinces. Pages 2029 in Eider Ducks in Canada. Edited by A. Reed. Canadian Wildlife Service Report Series Number 47. Canadian Wildlife Service, Environment Canada, Ottawa, Ont. 177 pages.

Gauthier, J., J. Bédard, and A. Reed. 1976. Overland migration by Common Eiders of the St. Lawrence estuary. Wilson Bulletin 88: 333-344.
Goudie, R. I., G. J. Robertson, and A. Reed. 2000. Common Eider (Somateria mollissima). Number 546 in the Birds of North America, edited by A. Poole. Cornell Lab of Ornithology, Ithaca, N.Y. Birds of North America Online, http://bna.birds.cornell.edu/bna/species/546doi:10.2173/ bna.546 (accessed 5 November 2008).

MacKinnon, C. M. 2000. The marsh barns of the Tantramar; end of an era. The White Fence (newsletter of the Tantramar Heritage Trust, Sackville, N.B.): 11 (Spring), http:// heritage.tantramar.com/WFNewsletter_11.html (accessed 11 August 2010).

MacKinnon, C. M., and A. C. Kennedy. 2009. Canada Lynx, Lynx canadensis, use of the Chignecto Isthmus and the possibility of gene flow between populations in New Brunswick and Nova Scotia. Canadian Field-Naturalist 122: 166-168.

Nature New Brunswick. 2008. Nature NB website and archives of the Nature NB listserve. Nature NB, Fredericton, N.B., http://www.naturenb.ca/ and NATURENB@ LISTSERV.UNB.CA (accessed 1 December 2008).

Tufts, R. W. 1961. The Birds of Nova Scotia. Nova Scotia Museum, Rolph-Clark-Stone, Maritimes Limited, Halifax, N.S. 481 pages.

Received 17 December 2010

Accepted 23 March 2011 